\title{
PENGARUH ETOS KERJA, DISIPLIN KERJA DAN KOMITMEN KARYAWAN TERHADAP KINERJA KARYAWAN PADA PUSKESMAS ARO KECAMATAN MUARA BULIAN
}

\author{
Sri Rosmawati, Ade Jermawinsyah
}

STIE Graha Karya Muara Bulian, Jambi, Indonesia

\begin{abstract}
This study aims to determine the effect of work ethics, work discipline and employee commitment at Aro Puskesmas in Muara Bulian District. This study included descriptive verification research. The population of this study was 56 people. By using a Likert scale, it shows the variables of work ethics, work discipline and employee commitment are in a good category. And multiple regression to determine the relationship of work ethic, work discipline and employee commitment to the Aro Health Center in Muara Bulian District. The results of the study and discussion show that work ethic has a negative effect on employee performance, while work discipline variables and employee commitment variables have a positive effect on employee performance at Aro Health Center in Muara Bulian District. Simultaneously shows that work ethics, work discipline and employee commitment show an influence on employee performance. With the value of $R$ Square of 0.725 , this shows that work ethic, work discipline and employee commitment affect work performance as much as $72.5 \%$ and the rest is influenced by other variables not examined in this study.
\end{abstract}

Keyword: work ethic, discipline, commitment, performance

\section{PENDAHULUAN}

Dengan diberlakukannya UU Nomor 22 tahun 1999 tentang pemerintahan daerah dan UU Nomor 25 tahun 1999 tentang perimbangan keuangan antara pemerintah pusat dan daerah, pemerintah daerah dituntut untuk meningkatkan kinerjanya dalam rangka memberikan pelayanan kepada masyarakat. Pada hakekatnya penyelenggaraan otonomi daerah adalah untuk pemberdayaan masyarakat, menumbuhkan prakarsa dan kreativitas daerah secara aktif, meningkatkan peran dan fungsi DPRD. Format kebijakan otonomi daerah menandai awal dari suatu perubahan fundamental dalam paradigma penyelenggaraan pemerintahan di Indonesia.

Pemerintahan yang baik (good governance) merupakan issue yang paling hangat dalam sektor publik dewasa ini dan merupakan prasyarat utama untuk dapat mewujudkan aspirasi masyarakat dalam mencapai tujuan dan cita-cita bangsa dan negara. Untuk itu diperlukan pengembangan dan penerapan sistem pertanggungjawaban yang tepat, jelas dan nyata, sehingga penyelenggaraan pemerintahan, pembangunan dan kemasyarakatan dapat berlangsung secara berdayaguna dan berhasilguna, bersih dan bertanggungjawab. Tuntutan yang gencar yang dilakukan oleh masyarakat kepada pemerintah untuk melaksanakan penyelenggaraan pemerintahan yang baik adalah sejalan dengan meningkatnya tingkat pengetahuan masyarakat, disamping adanya pengaruh globalisasi. Oleh karena itu tuntutan tersebut merupakan hal yang wajar dan sudah seharusnya direspon oleh pemerintah dengan melakukan perubahanperubahan yang terarah pada terwujudnya penyelenggaraan pemerintahan yang baik.

Dalam pelaksanaan pemerintahan yang baik, pemerintah dituntut untuk melaksanakan pelayanan publik baik berbentuk pelayanan barang publik maupun pelayanan jasa. Pusat Kesehatan Masyarakat (PUSKESMAS) sebagai salah satu sarana kesehatan yang memberikan pelayanan kesehatan kepada masyarakat memiliki peran yang sangat strategis dalam mempercepat peningkatan derajat kesehatan masyarakat. Oleh karena itu puskesmas dituntut untuk memberikan pelayanan yang bermutu yang memuaskan 
bagi pasiennya sesuai dengan standar yang ditetapkan dan dapat menjangkau seluruh lapisan masyarakatnya.

Sesuai dengan Undang-Undang Nomor 32 Tahun 2004 tentang Pemerintahan Daerah pada Bab IV pasal 11 ayat (2) ditetapkan bahwa bidang pemerintahan yang wajib dilaksanakan oleh daerah kabupaten dan daerah kota adalah pekerjaan umum, kesehatan, pendidikan, kebudayaan, pertanian, perhubungan, industri, perdagangan, penanaman modal, lingkungan hidup, pertanahan, koperasi, dan tenaga kerja. Berdasarkan undangundang tersebut, bidang kesehatan menempati urutan kedua (setelah bidang pekerjaan umum) dari bidang pemerintahan yang wajib dilaksanakan oleh pemerintah daerah kabupaten dan kota. Ini berarti bahwa dalam rangka otonomi daerah, pemerintah kabupaten dan pemerintah kota bertanggung jawab sepenuhnya dalam penyelenggaraan pembangunan kesehatan untuk meningkatkan derajat kesehatan masyarakat di wilayahnya, dengan memberikan pelayanan yang memuaskan.

$$
\text { Masih banyaknya anggota }
$$

masyarakat yang mengeluh dan merasa tidak puas dengan pelayanan yang diberikan oleh Puskesmas milik pemerintah ini baik dari segi pemeriksaan yang kurang diperhatikan oleh petugas kesehatan, lama waktu pelayanan, keterampilan petugas, sarana atau fasilitas, serta waktu tunggu untuk mendapatkan pelayanan akan menjadi dasar bagi pemerintah untuk meningkatkan kinerja pegawai dalam memberikan pelayanan kepada masyarakat.

Rendahnya kinerja pelayanan akan membangun citra buruk pada Puskesmas, dimana pasien yang merasa tidak puas akan menceritakan kepada rekan-rekannya. Begitu juga sebaliknya, semakin tinggi kinerja pelayanan yang diberikan akan menjadi nilai tambah bagi Puskesmas, dalam hal ini pasien akan merasa puas terhadap pelayanan yang diberikan oleh Puskesmas. Puskesmas dapat mengetahui kinerja pelayanan dari para pasien melalui umpan balik yang diberikan pasien kepada
Puskesmas tersebut sehingga dapat menjadi masukan untuk peningkatan kinerja pelayanan.

Kinerja karyawan (prestasi kerja) adalah hasil kerja secara kualitas dan kuantitas yang dicapai oleh seseorang karyawan dalam melakasanakan tugasnya sesuai dengan tanggung jawab yang diberikan kepadanya(Mangkunegara 2012:9). Kinerja dikatakan tinggi apabila suatu target kerja dapat diselesaikan pada waktu yang tepat atau tidak melampui batas waktu yang disediakan. Banyak faktor yang dapat mempengaruhi kinerja, antara lain Etos kerja, Motivasi, Kepemimpinan, Lingkungan kerja, Disiplin kerja, Budaya kerja, Komunikasi, Komitmen, Jabatan, Kualitas kehidupan kerja, Pelatihan, Kompensasi, Kepuasan kerja, dan masih banyak yang lain. Semua faktor tersebut berpengaruh, tergantung pada fakta yang terjadi sebenarnya, ada yang dominan dan ada pula yang tidak.

Demikian juga dengan Puskesmas Aro Kecamatan Muara Bulian Kabupaten Batang Hari adalah Unit Pelaksana Teknis Dinas Kesehatan Kabupaten yang bertanggung jawab menyelenggarakan pembangunan kesehatan di suatu wilayah kerja Kecamatan Muara Bulian. Penilaian prestasi pada Puskesmas Aro dilihat dari sejauh mana tingkat kedisiplinan, ketertiban dan tanggung jawab karyawan. Karyawan yang datang terlambat akan dikenakan sanksi berupa potongan gaji atau biasa disebut tunjangan kehadiran.

Salah satu faktor yang mempengaruhi prestasi kerja karyawan adalah komitmen karyawan yang ditunjukkan oleh tingkat kedisiplinan dalam hal ini tingkat kehadiran karyawan dalam bekerja. Etos kerja, Displin kerja dan komitmen karyawan sangat berpengaruh dalam usaha pencapaian tujuan organisasi yang optimal dalam peningkatan prestasi kerja dalam suatu organisasi.

\section{METODE PENELITIAN}

Metode penelitian yang digunakan dalam penelitian ini adalah deskriptif dan 
verifikatif. Data yang digunakan dalam penelitian ini merupakan data primer yang diperoleh dengan cara melakukan wawancara secara langsung dengan pihakpihak yang berhubungan dengan penelitian yang dilakukan dan penyebaran kuesioner kepada pegawai di Puskesmas Aro Kecamatan Muara Bulian yang berjumlah sebanyak 56 orang.

\section{Alat Analisa}

Alat analisa yang digunakan dalam penelitian ini adalah skala likert. Dengan skala likert variabel - variabel dijabarkan menjadi indikator variabel. Kemudian indikator variabel tersebut digunakan sebagai tolak ukur untuk instrument yang berupa pertanyaan dan jawaban.

\section{Analisis Deskripsi Variabel}

Analisis ini merupakan analisa terhadap variabel Etos kerja, Disiplin kerja dan Komitmen karyawan yang mempengaruhi Kinerja Karyawan pada Puskesmas Aro Kecamatan Muara Bulian. Dimana untuk melakukan analisa ini dilakukan berdasaran hasil jawaban respondan nods macins - masing per1 $Y=a+b_{1} X_{1}+b_{2} X_{2}+b_{3} X_{3} \quad$ tnalisa dilakukan dengan menggunakan nilai indeks yaitu dengan menentukan nilai besarnya kelas sebagai berikut :

Nilai Maksimum : 5

Nilai Minimum : 1

\section{- $\quad$ nilai maksimum - nilai minimum)}

\section{Rentang Skala $=\quad$ Jumlah indeks}

$$
=\underline{(5-1)} / 5=0,8
$$

Jadi, tabel indeks penilaian adalah sebagai berikut :

Tabel 1. Indeks Penilaian

\begin{tabular}{cc}
\hline Nilai Indeks & Pernyataan \\
\hline $1<\mathrm{x} \leq 1,8$ & Sangat Tidak Baik \\
$1,8<\mathrm{x} \leq 2,6$ & Tidak Baik \\
$2,6<\mathrm{x} \leq 3,4$ & Cukup Baik \\
$3,4<\mathrm{x} \leq 4,2$ & Baik \\
$4,2<\mathrm{x} \leq 5$ & Sangat Baik \\
\hline
\end{tabular}

Uji Methode Succesive Interval (MSI)
Metode yang digunakan dalam penelitian ini adalah metode kuantitatif.dimana variabel $\mathrm{X}_{1}$ (Etos kerja), Variabel $\mathrm{X}_{2}$ (Disiplin kerja) dan Variabel $\mathrm{X}_{3}$ (Komitmen karyawan) data variabel $\mathrm{Y}$ (Kinerja) yang dikumpulkan melalui kuesioner masih memiliki skala ordinal, maka sebelum diolah data ordinal terlebih dahulu dikonversi menjadi data interval menggunakan Methode Succesive Interval (MSI).

Menggunakan skala dengan rumus.

$$
\mathrm{NS}=\frac{(\text { Density at Lower Limit })-(\text { Density at Upper Limit })}{(\text { Area Below Upper Limit })-(\text { Area Below Upper Limit })}
$$

Proses pentransformasian data ordinal menjadi data interval dalam penelitian ini menggunakan bantuan program komputer yaitu Microsoft OfficeExcel 2013. Kemudian dilakukan uji validitas dan reliabilitas. Untuk melihat pengaruh etos kerja, disiplin kerja dan komitmen karyawan terhadap kinerja karyawan dilakukan analisis regresi berganda. Analisis regresi ini dinyatakan dengan persamaan sebagai berikut :

Dimana :

$\mathrm{Y}=$ Kinerja

$\mathrm{X}_{1}=$ Etos kerja

$\mathrm{X}_{2}=$ Disiplin kerja

$\mathrm{X}_{3}=$ Komitmen karyawan

$\alpha=$ Bilangan konstanta

$\mathrm{b}_{1}=$ Koefisien regresi Etos kerja

$b_{2}=$ Koefisien regresi Disiplin kerja

$\mathrm{b}_{3} \quad=$ Koefisien regresi Komitmen karyawan.

Selanjutnya dilakukan uji statistik berupa uji t dan uji $F$.

\section{HASIL DAN PEMBAHASAN}

Berdasarkan data yang diperoleh, tanggapan responden terhadap etos kerja pada Puskesmas Aro Kecamatan Muara Bulian menunjukkan hasil tertinggi adalah 3.73,yang terendah 3.50 dan rata-rata indeks dari 6 pertanyaan atau pernyataan di 
atas adalah 3.61. Berdasarkan dari hasil rata-rata indeks tabel diatas membuktikan bahwa variabel Etos kerja pada Puskesmas Aro Kecamatan Muara Bulian berada pada kategori Baik.

Disiplin kerja pada Puskesmas Aro Kecamatan Muara Bulian, berdasarkan tanggapan responden terhadap Disiplin kerja berdasarkan data yang diperoleh hasil tertinggi adalah 3.82, yang terendah 3.41 dan rata-rata indeks dari 6 pertanyaan atau pernyataan di atas adalah 3.64. Berdasarkan dari hasil rata-rata indeks diatas membuktikan bahwa variabel Disiplin kerja pada Puskesmas Aro Kecamatan Muara Bulian berada pada kategori Baik.

Tanggapan responden terhadap Komitmen karyawan berdasarkan hasil pengolahan dengan presentase dari enam aspek penilaian menunjukkan hasil tertinggi adalah 3.95, yang terendah 3.46 dan rata-rata indeks dari 6 pertanyaan atau pernyataan adalah 3.71. Hal ini membuktikan bahwa variabel Komitmen karyawan pada Puskesmas Aro Kecamatan Muara Bulian berada pada kategori Baik.
Tanggapan responden terhadap Kinerja pada Puskesmas Aro Kecamatan Muara Bulian adalah diketahui hasil pengolahan dengan presentase dari enam aspek penilaian menununjukkan hasil tertinggi adalah 4.02 , yang terendah 3.52 dan rata-rata indeks dari 6 pertanyaan atau pernyataan adalah 3.74. Berdasarkan dari hasil rata-rata indeks membuktikan bahwa variabel Kinerja karyawan pada Puskesmas Aro Kecamatan Muara Bulian berada pada kategori Baik.

\section{Pengaruh Etos kerja, Disiplin kerja dan Komitmen karyawan terhadap Kinerja karyawan pada Puskesmas Aro Kecamatan Muara Bulian Uji Validitas}

Dengan alpa sebesar 5\% maka menghasilkan nilai $r$ hitung lebih besar dari $\mathrm{r}$ tabel. Dasar pengambilan keputusan yang digunakan adalah melakukan uji signifikan dengan membandingkan nilai $r$ hitung dengan $r$ tabel. Untuk populasi 56 orang maka $\mathrm{r}$ tabel adalah 0.268. Maka hasil analisanya adalah sebagai berikut :

Tabel 2. uji signifikan dengan membandingkan nilai $r$ hitung dengan $r$ tabel

\begin{tabular}{ccccc}
\hline Variabel & Item Pertanyaan & r Hitung & r Tabel & Keterangan \\
\hline \multirow{3}{*}{ Etos Kerja } & 1 & 0.441 & 0.268 & Valid \\
& 2 & 0.654 & 0.268 & Valid \\
& 3 & 0.644 & 0.268 & Valid \\
& 4 & 0.632 & 0.268 & Valid \\
Disiplin Kerja & 5 & 0.607 & 0.268 & Valid \\
& 6 & 0.649 & 0.268 & Valid \\
& 1 & 0.386 & 0.268 & Valid \\
& 2 & 0.551 & 0.268 & Valid \\
Komitmen Karyawan & 3 & 0.552 & 0.268 & Valid \\
& 4 & 0.607 & 0.268 & Valid \\
& 5 & 0.600 & 0.268 & Valid \\
& 6 & 0.642 & 0.268 & Valid \\
& 1 & 0.491 & 0.268 & Valid \\
& 2 & 0.610 & 0.268 & Valid \\
& 3 & 0.576 & 0.268 & Valid \\
& 4 & 0.587 & 0.268 & Valid \\
& 5 & 0.652 & 0.268 & Valid \\
& 6 & 0.670 & 0.268 & Valid \\
& 1 & 0.442 & 0.268 & Valid \\
& 2 & 0.624 & 0.268 & Valid \\
& 3 & 0.576 & 0.268 & Valid \\
& 4 & 0.588 & 0.268 & Valid \\
& 5 & 0.604 & 0.268 & Valid \\
& 5 & 0.560 & 0.268 & Valid \\
\hline
\end{tabular}


Berdasarkan tabel diatas, dapat diketahui semua item pertanyaan secara keseluruhan dinyatakan valid dan dapat digunakan untuk mendukung penelitian ini.

\section{Uji Realibilitas}

Uji realibilitas dilakukan untuk mengetahui ketepatan dari alat ukur yang digunakan dalam penelitian. Perhitungan realibilitas harus dilakukan hanya pada item-item yang sudah memiliki validitas. Suatu variabel dikatakan realiabel jika memiliki nilai Cronbach's Alpha> 0.5 . Hasil uji realibilitas dari penelitian ini adalah sebagai berikut:

Tabel 3. Hasil uji realibilitas

\begin{tabular}{lllll}
\hline No & Variabel & Cronbach's alpha & r Tabel & Keterangan \\
\hline $\mathbf{1}$ & Etos Kerja & 0.644 & 0,5 & Reliabel \\
$\mathbf{2}$ & Disipilin Kerja & 0.544 & 0,5 & Reliabel \\
$\mathbf{3}$ & Komitmen Karyawan & 0.6 .27 & 0,5 & Reliabel \\
$\mathbf{4}$ & Kinerja & 0.566 & 0,5 & Reliabel \\
\hline
\end{tabular}

Berdasarkan tabel diatas, dapat diketahui bahwa keseluruhan variabel lebih besar dari nilai Cronbach's Alpha dari pada tingkat signifikasinya. Hal ini membuktikan bahwa keseluruhan variabel dinyatakan reliabel dalam penelitian ini.

\section{Regresi Linear Berganda}

Untuk mengetahui perhitungan hasil Regresi Linear Berganda dapat dilihat pada tabel sebagai berikut :

Tabel 4. Hasil Regresi Linear Berganda

\begin{tabular}{|c|c|c|c|c|c|c|}
\hline & \multirow[t]{2}{*}{ Model } & \multicolumn{2}{|c|}{$\begin{array}{l}\text { Unstandardized } \\
\text { Coefficients }\end{array}$} & \multirow{2}{*}{$\begin{array}{c}\text { Standardized } \\
\text { Coefficients }\end{array}$} & \multirow[t]{2}{*}{$\mathrm{t}$} & \multirow[t]{2}{*}{ Sig. } \\
\hline & & B & Std. Error & & & \\
\hline \multirow[t]{4}{*}{1} & (Constant) & 2.806 & 1.734 & & 1.618 & .112 \\
\hline & $\mathrm{X}^{1}$ & -.436 & .147 & -.443 & -2.976 & .004 \\
\hline & $X^{2}$ & .808 & .165 & .724 & 4.889 & .000 \\
\hline & $\mathrm{X}^{3}$ & .513 & .128 & .556 & 3.999 & .000 \\
\hline
\end{tabular}

a. Dependent Variable: Y

Hasil perhitungan Regresi Linear Berganda dengan program spss versi 24 dari tabel koefisien, diperoleh persamaan sebagai berikut :

$\mathrm{Y}=\mathrm{a}+\mathrm{b} 1 . \mathrm{X} 1+\mathrm{b} 2 . \mathrm{X} 2+\mathrm{b} 3 . \mathrm{X} 3$

$\mathrm{Y}=2.806+(-0.436) \mathrm{X} 1+0.808 \mathrm{X} 2+0.513$ $\mathrm{X}_{3}$

Dari persamaan diatas dapat dijelaskan Bahwa nilai a (Konstanta) sebesar 2.806 dan nilai koefisien regresi atau nilai pengaruh b1 sebesar (-0.436), nilai pengaruh b2 sebesar 0,808 dan nilai pengaruh $b_{3}$ sebesar 0.513 . Ini menjelaskan berarti terdapat pengaruh yang positif dalam penelitian ini. Persamaan diatas juga dapat diartikan sebagai berikut :

1. $\mathrm{a}=2.806$

Artinya apabila variabel Etos kerja, Disiplin Kerja dan Komitmen karyawanbernilai nol maka tingkat Kinerja karyawan adalah sebesar 2.806

2. $\mathrm{b}_{1} . \mathrm{X}_{1}=$ Etos kerja $=(-0.436)$

Artinya apabila variabel Etos kerja rendah maka variabel Kinerja juga akan menurun sebesar (-0.436)satuan dengan asumsi variabel lain tetap.

3. $b_{2} \cdot X_{2}=$ Disiplin Kerja $=0.808$

Artinya apabila variabel Disiplin kerja naik sebesar satu satuan maka variabel Kinerja karyawan juga akan meningkat sebesar 0,808 satuan dengan asumsi variabel lain tetap.

4. $b_{3} \cdot X_{3}=$ Komitmen $=0.513$

Artinya apabila variabel Komitmen naik sebesar satu satuan maka variabel Kinerja karyawan juga akan meningkat sebesar 0,513. satuan dengan asumsi variabel lain tetap. 


\section{Uji Parsial (Uji t)}

Uji t bertujuan untuk mengetahui ada tidaknya pengaruh parsial (sendiri) yang diberikan variabel bebas (X) terhadap variable terikat $(\mathrm{Y})$. Dalam penelitian ini juga menggunakan bantuan SPSS versi 24 yang mana hasil uji $\mathrm{t}$ dapat dilihat pada tabel (Coefficients). Diuji dengan tingkat signifikan $t$ tabel $=t(\alpha / 2: n-k-1)$ $=\mathrm{t}(0.025: 56-3-1=52)=2.00665 \mathrm{dan}$ Ho diterima apabila signifikan $>2.00665$ dan Ho sebaliknya Ho ditolak apabila signifikan $<2.00665$.

1. Nilai $\mathrm{t}$ hitung dari koefisien regresi untuk Etos kerja sebesar (2.976). Karena $\mathrm{t}$ hitung $(-2.976)<2.00665$ maka Ho tolak. Jadi dapat disimpukan bahwa variabel Etos kerja tidak berpengaruh signifikan terhadap variabel Kinerja Karyawan pada Puskesmas Aro Kecamatan Muara Bulian.

2. Nilai $t$ hitung dari koefisien regresi untuk Disiplin kerja sebesar4.889.
Karena t hitung $4.889>2.00665$ maka Ho terima, Jadi dapat disimpukan bahwa variabel Disiplin kerja berpengaruh signifikan terhadap variabel Kinerja karyawan pada Puskesmas Aro Kecamatan Muara Bulian.

3. Nilai $t$ hitung dari koefisien regresi untuk Komitmen karyawan sebesar 3.999. Karena t hitung $3.999>2.00665$ maka Ho terima, Jadi dapat disimpukan bahwa variabel Komitmen karyawan berpengaruh signifikan terhadap variabel Kinerja karyawan pada Puskesmas Aro Kecamatan Muara Bulian.

\section{Uji Simultan (Uji F)}

Uji $\mathrm{F}$ bertujuan untuk mengetahui ada tidaknya pengaruh simultan (bersamasama) yang diberikan variabel bebas (X) terhadap variable terikat (Y).Untuk mengetahui hasil dari uji $\mathrm{F}$ dapat dilihat pada tabel dibawah ini :

Tabel 5. Hasil Uji F

\begin{tabular}{|l|l|r|r|r|r|r|}
\hline \multicolumn{2}{|c|}{ Model } & Sum of Squares & df & Mean Square & \multicolumn{1}{c|}{ F } & Sig. \\
\hline \multirow{4}{*}{1} & Regression & 197.948 & 3 & 65.983 & 49.293 & $.000^{\mathrm{b}}$ \\
\cline { 2 - 8 } & Residual & 69.606 & 52 & 1.339 & & \\
\cline { 2 - 8 } & Total & 267.554 & 55 & & & \\
\hline
\end{tabular}

a. Dependent Variable: KINERJA

b. Predictors: (Constant), KOMITMEN KARYAWAN, DISIPLIN KERJA, ETOS KERJA

Dari Uji Simultan (Uji F) maka dapat disimpulkan bahwa variabel Etos kerja, Disiplin kerja, dan Komitmen karyawan menunjukkan adanya pengaruh yang signifikan terhadap Kinerja karyawan pada Puskesmas Aro Kecamatan Muara Bulian yang dibuktikan dengan nilai $\mathrm{F}$ hitung 49.293 lebih besar dari F tabel 2.78.

Tabel 6. Hasil Nilai Uji F

\begin{tabular}{|c|c|c|c|c|}
\hline Model & R & R Square & Adjusted R Square & Std. Error of the Estimate \\
\hline 1 & $.860^{\mathrm{a}}$ & .740 & .725 & 1.15697 \\
\hline
\end{tabular}

a. Predictors: (Constant), KOMITMEN KARYAWAN, DISIPLIN KERJA, ETOS KERJA

\section{Koofesien Determinasi $\left(R^{2}\right)$}

Untuk mengetahui nilai Koefisien determinasi, bisa dilihat dari pengelolahan data menggunakan spss 24 pada tabel $\mathrm{R}^{2}(R$ Square). Pada tabel perhitungan SPSS $\mathrm{R}^{2}$ ( $\mathrm{R}$ Square) dapat diketahui nilai $\mathrm{R}^{2}$ ( $\mathrm{R}$ Square) sebesar 0.725 ini berarti bahwa variabel Etos kerja, Disiplin kerja dan Komitmen karyawan memberikan pengaruh sebesar $72.5 \%$ terhadap Kinerja karyawan Pada Puskesmas Aro Kecamatan Muara Bulian. Sedangkan 27.5\% lagi depengaruhi oleh variabel lain yang tidak diteliti dalam penelitian ini. 


\section{SIMPULAN}

Berdasarkan hasil penelitian dan pembahasan, maka kesimpulan yang dapat diambil adalah sebagai berikut :

1. Berdasarkan hasil tanggapan responden tentang variabel Etos kerja pada Puskesmas Aro Kecamatan Muara Bulian dengan jumlah nilai rata - rata indeks adalah 3.61. ini membuktikan bahwa variabel Etos kerja pada Puskesmas Aro Kecamatan Muara Bulian berada pada kategori Baik.

2. Berdasarkan hasil tanggapan responden tentang variabel Disipllin kerja pada Puskesmas Aro Kecamatan Muara Bulian dengan jumlah nilai rata - rata indeks adalah 3.64. ini membuktikan bahwa variabel Disiplin kerja pada Puskesmas Aro Kecamatan Muara Bulian berada pada kategori Baik.

3. Berdasarkan hasil tanggapan responden tentang variabel Komitmen karyawan pada Puskesmas Aro Kecamatan Muara Bulian dengan jumlah nilai rata - rata indeks adalah 3.71. ini membuktikan bahwa variabel Komitmen kayawan pada Puskesmas Aro Kecamatan Muara Bulian berada pada kategori Baik.

4. Berdasarkan hasil tanggapan responden tentang variabel Kinerja pada Puskesmas Aro Kecamatan Muara Bulian dengan jumlah nilai rata - rata indeks adalah 3.74. ini membuktikan bahwa variabel Kinerja pada Puskesmas Aro Kecamatan Muara Bulian berada pada kategori Baik.

Berdasarkan dari perhitungan regresi berganda diperoleh bahwa secara simultan variabel Etos kerja tidak berpengaruh terhadap variabel Kinerja Karyawan pada Puskesmas Aro Kecamatan Muara Bulian. Sedangkan untuk disiplin kerja dan komitmen karyawan berpengaruh positif terhadap kinerja karyawan pada Puskesmas Aro Kecamatan Muara Bulian

\section{DAFTAR PUSTAKA}

Arikunto S. 2006. Prosedur Penelitian Suatu Pendekatan Praktik.Jakarta: PT RinekaCipta.
Dayanto. 2013. Pengantar ilmu manajemen dan komunikasi. Jakarta : PT. Prestasi Pustakaraya.

Edison E. 2017. Manajemen sumberdaya manusia. Bandung: Alfabeta.

Handoko. 2011.Manajemen Personalia dan Sumberdaya Manusia. Yogyakarta: Penerbit BPFE.

HasibuanMalayu S. P. 2015. Manajemen Sumberdaya Manusia. Jakarta: PT. BumiAksara.

Luthans Fred. 2009.Perilaku Organisasi. Edisi Sepuluh. Yogyakarta: Andy Offset.

Mangkunegara. 2012. Evaluasi Kinerja Sumber Daya Manusia. Bandung:PT. Refika Aditama.

Mangkunegara. 2013. Manajemen Sumber Daya Manusia Perusahaan. Bandung: Remaja Rosdakarya.

Mulyadi. 2010. Relasi Antara Kualitas Keagmaan dengan Etos Kerja di Daerah Kawasan Industri Kabupaten Bekasi. Bekasi: Manajemen pendidikan UNISMA.

Rivai, Veithzal. 2013. Manajemen Sumberdaya Manusia Untuk Perusahaan Dari teori ke praktik. Jakarta: Raja Grafindo Persada.

Robbins SP, Judge. 2008. Perilaku Organisasi buku 2. Jakarta: Salemba.

Sagian. P. Sodang. 2007. Manajemen Sumberdaya Manusia. Jakarta : PT. Akrasa.

Samsudin, Sadili. 2010. Manajemen Sumber Daya Manusia. Bandung: Pustaka Setia

Sedarmayanti. 2011. Manajemen Sumber Daya Manusia. Reformasi Birokrasi dan Manajemen Pegawai Negeri Sipil. Bandung: PT Refika Aditama.

Siagian. 2012. Manajemen sumber daya manusia. Jakarta: PT. BumiAksara.

Sinamodalam Hadiansyah A. 2015. Pengaruh Etos Kerja Terhadap Kinerja Karyawan pt. ae.Jurnal alazharindonesiaserihumaniora $_{2} \quad 3$, 150-158. 
Sinamo, Jansen. 2011. Delapan Etos Kerja Profesional. Jakarta: Institut Dharma Mahardika

STIE-GK. 2018. Buku Panduan Penulisan Skripsi. STIE-GK MuaraBulian.

Sugiono. 2009. Methodologi Penelitian Administrasi. Cetakan ke 17. Bandung: Alfabeda.

Sugiono. 2008. Methode Penelitian Bisnis. Bandung: Alfabeta.

Sugiono. 2009. Statistika untuk penelitian. Bandung: Alfabeta.

Sutrisno, Edi. 2011. Manajemen sumber daya manusiaedisi pertama. Jakarta: Kencana Prenada Media Group.

Terry G.R. 2010. Manajemen Sumber Daya Manusia. Jakarta: PenerbitKencana.

Wahyudi. 2010.Manajemen Sumber DayaManusia.Jakarta:Sulita.

Wibowo. 2010. Manajemen Kinerja.Jakarta: Rajawali Press.

Zurnali. 2010. Learning organization, competency, organizational commitment, dan customer orientation : knowledge worker.kerang kariset manajemen sumberdaya manusia pada masa depan. Bandung:Unpad Press. 